\title{
USGS Western Coastal and Marine Geology Team, 2004
}

he Western Coastal and Marine
Geology Team of the U.S. Geo-
logical Survey (USGS) studies the
Pacific coast of the Western United
States. Team scientists conduct
marine research, monitor ocean
processes, and provide information
about geologic hazards, environmen-
tal conditions, habitats, and energy
and mineral resources. USGS activi-
ties help managers at all levels of
government and in the private sector
make informed decisions about
the use and protection of national
coastal and marine resources.

\section{Locations and Personnel}

The Western Coastal and Marine Geology Team consists of about 120 people located in Santa Cruz and Menlo Park, California. Work and staff are integrated with the other USGS Coastal and Marine Geology centers in Woods Hole, Massachusetts, and St. Petersburg, Florida.

\section{Examples of Current Research}

Tsunami Hazards: USGS researchers are working with the National Oceanic and Atmospheric Administration (NOAA) and other organizations to develop probabilistic inundation-hazard maps for use by the Federal Emergency Management Agency (FEMA). They are also seeking evidence of ancient tsunamis in southern California that may be associated with the huge landslide deposits identified in offshore bathymetric and seismic-reflection data.

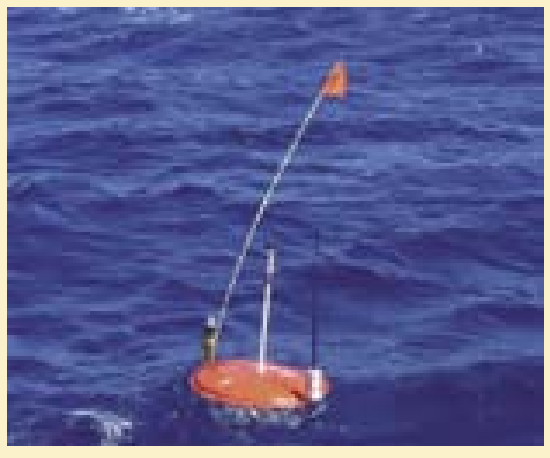

Drifter equipped with navigation system and radio transmitter tracks the movement of newly spawned coral larvae in Hawaii.
Benthic Habitats: Sea-floor characteristics affect the distribution, abundance, and behavior of bottom-dwelling fish and shellfish of commercial and recreational value. USGS scientists are mapping benthic (sea floor) habitats offshore California and Alaska to better understand seabed dynamics and to support State and national management efforts.

Landslides: Team scientists are using ground-penetrating radar and other remote-sensing tools to study landslides and ground failures in coastal environments of central California, Puget Sound (Washington), and Alaska. A project with the California Department of Transportation (Caltrans) is investigating recent and historical landslides along the Big Sur coast to assess the hazard for California Highway 1 and to determine impacts on the coastal environment.

Coral Reefs: USGS scientists are mapping the distribution and condition of coral reefs as part of a national effort to understand and protect these fragile environments. Projects are underway in Hawaii in cooperation with the National Park Service, the University of Hawaii, and others.

\section{Puget Sound Nearshore Project: USGS} scientists are investigating present-day water-circulation and sediment-transport patterns in nearshore environments of Puget Sound, Washington, to document the characteristics, evolution, and geologic processes of estuarine and marine habitats. This work contributes to the Puget Sound Nearshore Ecosystem Restoration Project, a cooperative effort involving the U.S. Army Corps of Engineers and many State and local agencies.

Southern California Sediment: Team scientists are studying the distribution of sediment and pollutants offshore heavily populated southern California. The U.S. Environmental Protection Agency (EPA) and local sanitation districts help support this work, which includes investigating and modeling processes that transport sediment and pollutants through coastal waters.

Earthquake Hazards: The USGS is mapping and documenting the locations, geometry, slip rates, and earthquake-recurrence intervals of active faults offshore California and the Pacific Northwest - in- formation essential for seismic-hazard assessment and mitigation.

Extreme-Event Response: After wildfires ravaged southern California in fall 2003, USGS researchers deployed instruments off the Santa Clara River, which drains one of the largest coastal watersheds in the region. These instruments recorded the transport of a large volume of sediment washed to the ocean by erosion of the denuded slopes. A followup coring study was conducted to determine the amount and chemical composition of this sediment and its effects on the marine environment.

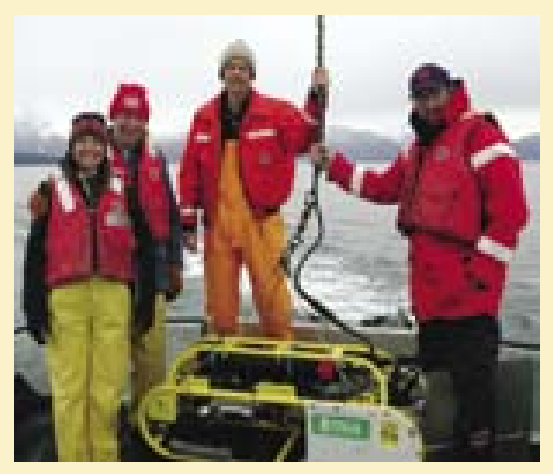

U.S. Geological Survey scientists about to deploy a video sled to study benthic habitats in Glacier Bay, Alaska.

Dam Removal: Thousands of small dams in the United States will be removed during the 21st century, owing to their age or to ecosystem-restoration efforts. USGS scientists are preparing to monitor sediment released by the removal of two dams on the Elwha River in Washington in order to determine how this sediment affects local habitats and water quality.

\section{Helen Gibbons}

Edited by George A. Havach

Graphic design by Stephen L. Scott

For more information contact:

Dr. Samuel Y. Johnson, Chief Scientist

USGS Pacific Science Center 400 Natural Bridges Dr. Santa Cruz, CA 95060

(831) 427-4746, sjohnson@usgs.gov http://walrus.wr.usgs.gov/

This Fact Sheet and any updates to it are available online at http://pubs.usgs.gov/fs/2004/3075/ 